\title{
KEPUASAN PETANI PADI TERHADAP PELAKSANAAN BAURAN PEMASARAN BENIH PADI BERSERTIFIKAT NON SUBSIDI - PT. PERTANI CABANG PEMASARAN KARAWANG
}

\author{
Satisfaction of Rice Farmers to the Implementation of the Marketing Mix of Non \\ Subsidized Certified Rice Seeds - PT. Pertani Cabang Pemasaran Karawang
}

\author{
Devi Maulidia* dan Eti Suminartika \\ Program Studi Agribisnis Fakultas Pertanian Universitas Padjadjaran \\ Jl. Raya Bandung Sumedang km. 21, Jatinangor, 40600, Indonesia \\ *Alamat korespondensi: devimaulidia@yahoo.com
}

\begin{abstract}
ABSTRAK
PT.Pertani bergerak salah satunya di bidang produksi dan distribusi benih. Berdasarkan benih yang dipasarkannya, ada dua jenis konsumen benih padi PT. Pertani yaitu konsumen benih bersubsidi dan non subsidi. Penelitian ini dilakukan untuk menentukan kualitas bauran pemasaran benih padi bersertifikat non subsidi berdasarkan kepuasan petani padi sebagai konsumen benih. Penelitian dilakukan dengan teknik deskriptif kuantitatif yang mengidentifikasi tingkat kesesuaian antara kepentingan dan pelaksanaan bauran pemasaran yang dirasakan oleh petani padi, prioritas perbaikan bauran pemasaran, serta tingkat kepuasan petani. Terdapat tujuh atribut bauran pemasaran yang dinilai berdasarkan prinsip bauran pemasaran 7P dan dianalisis dengan metode Importance-Performance Analysis (IPA) dan Customer Satisfaction Index (CSI). Penelitian dilakukan di empat desa yang berada di wilayah Kios Tani Ramah, Kabupaten Karawang. Alasan pemilihan Kios Tani Ramah adalah karena kios ini adalah pemasar benih padi bersertifikat terbesar dari PT. Pertani Cabang Karawang, dimana PT. Pertani sendiri merupakan satu dari dua BUMN yang memproduksi benih padi bersertifikat. Variabel yang akan diteliti pada penelitian ini adalah bauran pemasaran 7P (Product, Price, Place, Promotion, People, Process, dan Physical Evidence). Hasil penelitian menunjukkan bahwa yang menjadi prioritas untuk ditingkatkan ialah atribut ketahanan hama, penyakit, kesesuaian harga dengan kualitas, promosi word of mouth, dan kebersihan kios. Tingkat kepuasan petani berdasarkan penilaian CSI yaitu $75,20 \%$ atau 0,752 yang berarti ada pada kriteria puas, karena berada diantara $0,66-0,80$.
\end{abstract}

Kata kunci: kepuasan petani, bauran pemasaran, benih padi bersertifikat, non subsidi, IPA

\begin{abstract}
One of PT.Pertani's business branch is seed production and distribution. Based on the seeds market, there are two types of consumers of PT. Pertani. Those are, subsidized and non-subsidized seed consumers. This research was conducted to determine the quality of marketing mix of certified rice seeds based on the satisfaction of the rice farmers as seed consumers. The research was conducted with quantitative descriptive analysis method that identifies the level of conformity between the importance and the implementation of the marketing mix perceived by the rice farmers, the priority of the marketing mix improvement, and the level of farmer satisfaction. There are seven marketing mix attributes that are judged by the $7 P$ marketing mix principle and analyzed by Importance-Performace Analysis (IPA) and Customer Satisfaction Index (CSI) method. The study was conducted in four villages located in Kios Tani Ramah area, Karawang Regency. The reason for choosing Tani Ramah Kiosk is because this kiosk is the largest certified rice seeds marketer from PT. Pertani Karawang Branch, where PT. Pertani itself is one of two state-owned enterprises that produce certified rice seeds. The variables to be sold in this study are 7P marketing mix (Product, Price, Place, Promotion, People, Process, dan Physical Evidence). The results showed that the priorities to be improved are the attribute of pest resistance, disease, price conformity with the quality, word of mouth promotion, and the kiosk's hygiene. The level of farmer satisfaction based on the CSI assessment is $75.20 \%$ or 0.752 which means it is within the "satisfied" criteria, because it is between $0.66-0.80$.
\end{abstract}

Keywords: farmer satisfaction, marketing mix, certified rice seed, non subsidized, IPA

\section{PENDAHULUAN}

Padi (oryza sativa) merupakan bahan

baku pangan pokok yang selalu tersedia bagi sebagian besar masyarakat Indonesia.

Kegiatan menanam padi di Indonesia pada awalnya banyak dilaksanakan di pulau 
Jawa. Namun sekarang kegiatan penanaman padi sudah dilaksanakan di sebagian besar daerah di Indonesia. Hal ini karena terdapat pemikiran bahwa beras akan selalu dibutuhkan oleh masyarakat. Padi sebagai kebutuhan pokok bagi $>95 \%$ masyarakat telah mampu memberikan lapangan kerja untuk 20 juta rumah tangga petani yang ada di pedesaan Indonesia (Sodikin, 2015).

Gambar 1 menunjukkan bahwa dalam kurun waktu sepuluh tahun (2006-2015), terdapat tiga provinsi yang memiliki jumlah produksi padi terbesar di Indonesia, yaitu Jawa Barat, Jawa Tengah, dan Jawa Timur. Provinsi Jawa Timur memimpin dengan jumlah produksi padi 112.503.215 ton selama sepuluh tahun. Selanjutnya terdapat provinsi Jawa Barat dengan jumlah produksi 110.510 .368 ton, dan diikuti oleh provinsi Jawa Tengah dengan jumlah produksi 97.113 .031 ton. Ketiga provinsi tersebut mengalami fluktuasi jumlah produksi selama sepuluh tahun. Namun dapat dilihat bahwa provinsi Jawa Timur mengalami kenaikan produksi pada tahun 2014 dan 2015, sedangkan provinsi Jawa Barat mengalami penurunan produksi dalam dua tahun terakhir.

Salah satu penyebab penurunan produksi padi yaitu sarana produksi yang digunakan petani padi. Pemakaian benih bersertifikat saat ini belum merataoleh petani padi di Indonesia (Sudjindro, 2009).

Benih merupakan calon dari kehidupan suatu tanaman yang kualitasnya harus unggul dan berdaya hasil tinggi. Berdasarkan Tabel 1. dalam kurun waktu lima tahun (2011-2015), secara umum terjadi penurunan penggunaan benih padi varietas unggul bersertifikat di Indonesia. Banyak petani yang masih menggunakan benih tidak bersertifikat yang merupakan hasil perbanyakan sendiri atau hasil pertukaran dengan petani lain. Padahal penggunaan benih dari varietas unggul dapat mendongkrak produksi pertanian (Sudjindro, 2009).

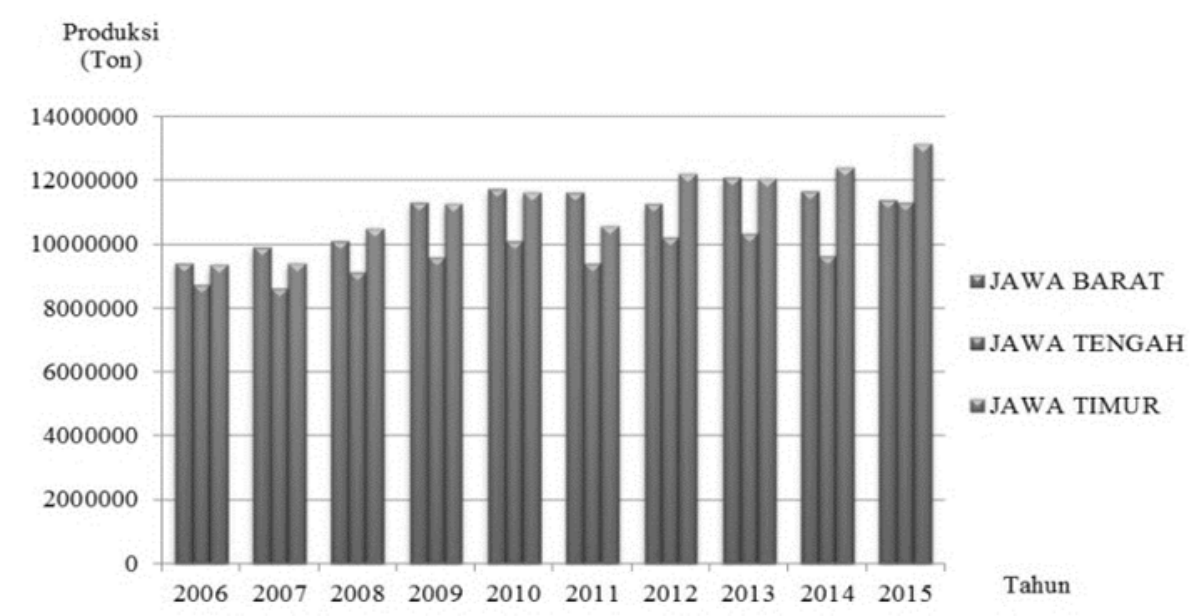

Gambar 1. Produksi padi terbesar di Indonesia, 2006-2015 (Sumber : BPS, 2016). 
Tabel 1. Persentase penggunaan benih padi bersertifikat di Indonesia, 2011-2015

\begin{tabular}{ccc}
\hline No & Tahun & Persentase Penggunaan Benih Bersertifikat (\%) \\
\hline 1 & 2011 & 64,86 \\
2 & 2012 & 55,93 \\
3 & 2013 & 46,63 \\
4 & 2014 & 45,90 \\
5 & 2015 & 47,94 \\
\hline
\end{tabular}

Sumber: Direktorat Pembenihan Tanaman Pangan, 2015.

Tabel 2. Jumlah benih padi subsidi dan non subsidi yang dipasarkan PT. Pertani Cabang Pemasaran Karawang, 2016-2017

\begin{tabular}{|c|c|c|c|c|}
\hline \multirow{2}{*}{ Jenis Pasar } & \multicolumn{2}{|c|}{ Kuantitas Benih yang Dipasarkan (kg) } & \multirow{2}{*}{ Total (kg) } & \multirow{2}{*}{ Total (ton) } \\
\hline & Tahun 2016 & Tahun 2017 & & \\
\hline Subsidi & 486.775 & 1.262 .085 & 1.748 .860 & $1.748,86$ \\
\hline Non Subsidi & 32.000 & 29.740 & 61.740 & 61,74 \\
\hline
\end{tabular}

Sumber: Analisa Data Primer, 2018.

Industri yang menangani produksi dan distribusi benih padi unggul di Indonesia ialah PT. Pertani dan PT. Sang Hyang Seri. PT. Pertani Cabang Pemasaran Karawang sendiri memasarkan benihnya ke Kabupaten Bekasi, Purwakarta, dan sebagian besar ke Kabupaten Karawang. Berdasarkan benih yang dipasarkannya, ada dua jenis konsumen benih padi PT. Pertani yaitu konsumen benih bersubsidi dan non subsidi.

Dalam dua tahun terakhir, tepatnya awal tahun 2016 hingga akhir tahun 2017, PT. Pertani ditunjuk oleh Dinas Pertanian untuk memproduksi dan memasarkan benih bersubsidi, para kelompok tani yang hanya membeli dengan harga $\mathrm{Rp} 2.500 / \mathrm{kg}$ benih kepada PT. Pertani, lalu sisanya ditanggung oleh pemerintah. Hal ini membuat perusahaan beralih fokus dari memproduksi dan mendistribusi benih non subsidi kepada produksi dan distribusi benih bersubsidi.
Namun konsumen benih non subsidi tetap dilayani dan tidak dibiarkan begitu saja, walaupun jumlahnya jauh berkurang semenjak adanya penunjukkan tersebut. Alasan PT. Pertani Cabang Pemasaran Karawang berusaha mempertahankan pemasaran benih non subsidi karena kebijakan pemerintah untuk mengadakan subsidi selalu berubah setiap tahunnya. Seperti yang terjadi pada awal tahun 2018 belum terdapat kebijakan pemerintah bagi PT. Pertani untuk melakukan subsidi benih bersertifikat seperti dua tahun sebelumnya, seharusnya kebijakan tersebut sudah ada sejak Desember 2017.

Tidak adanya kepastian untuk melakukan subsidi di tahun 2018 membuat PT. Pertani kini kembali berfokus pada produksi dan distribusi benih non subsidi. Fokus yang terlalu tinggi terhadap pemasaran benih bersubsidi di dua tahun sebelumnya mengakibatkan kehilangan 
banyak konsumen benih non subsidi. Hal yang menjadi penyebab adalah produsen benih swasta yang memanfaatkan kesempatan untuk mengambil alih pangsa pasar benih non subsidi PT. Pertani.

Permintaan petani akan benih unggul bersertifikat menyebabkan industri perbenihan khususnya benih padi mulai berkembang dan bersaing untuk memproduksi benih padi unggul. Kemunculan banyak pesaing di tengah kondisi pasar benih non subsidi yang telah direbut oleh pesaing membuat PT. Pertani sebagai salah satu perusahaan negara penyedia benih padi bersertifikat dengan segala strategi pemasarannya terus berupaya untuk meningkatkan kualitas dengan memberikan yang terbaik kepada petani sebagai konsumen.

Salah satu strategi pemasaran yang mampu mendukung penciptaan kepuasan konsumen adalah penggunaan bauran pemasaran. Apabila penilaian konsumen pada bauran pemasaran tersebut semakin baik, kinerja produk akan semakin baik (Darmayana dalam Mevita, 2015). Berdasarkan kondisi tersebut, sebagai pelaku bisnis, PT. Pertani khususnya Cabang Pemasaran Karawang perlu melakukan analisis terkait apakah bauran pemasarannya dapat diterima dengan baik atau tidak oleh petani yang membeli benih non subsidi tersebut. Dengan tercapainya kepuasan konsumen (petani), diharapkan peluang pasar akan meningkat, begitu juga dengan jumlah pembelinya. Oleh karena itu, tujuan penelitian ini adalah untuk mengetahui nilai kepuasan konsumen terhadap bauran pemasaran serta atributatribut yang menjadi priotitas untuk diperbaiki.

\section{METODE}

Objek pada penelitian ini adalah konsumen benih padi bersertifikat non subsidi produksi PT. Pertani. Tempat untuk penelitian ini adalah Desa Cintaasih, Desa Jatilaksana, Desa Kertasari, dan Desa Ciptasari, Kecamatan Pangkalan, Kabupaten Karawang. Pemilihan tempat dilakukan karena Desa Cintaasih adalah tempat Kios Tani Ramah berada, dan ketiga desa lainnya saling berdekatan dengan Desa Cintaasih. Kios Tani Ramah merupakan salah satu kios yang memasarkan benih non subsidi PT. Pertani terbanyak diantara kios lain yang ada di Kabupaten Karawang. Sehingga peluang memperoleh responden lebih besar. Penelitian dilaksanakan pada bulan Februari 2018.

Penelitian ini menggunakan desain deskriptif kuantitatif. Dengan pengambilan responden petani padi sebagai konsumen benih padi PT. Pertani, penelitian ini menggunakan teknik suatu kasus dengan metode survei.

Populasi dalam penelitian ini adalah 200 orang petani padi dengan asumsi supply 
p-ISSN: 1410-0029; e-ISSN2549-6786

Agrin Vol. 22, No. 2, Oktober 2018

benih ke kios adalah 5 ton per musim dan satu orang petani menggunakan $25 \mathrm{~kg}$ benih untuk 1 hektar lahannya. Pengambilan sampel dilakukan dengan metode simple random sampling, menggunakan Slovin dan didapatkan sebanyak 36 orang responden.

Variabel yang akan diteliti pada penelitian ini adalah bauran pemasaran $7 \mathrm{P}$ (Product, Price, Place, Promotion, People, Process, dan Physical Evidence) yang terdiri dari 17 atribut bauran pertanyaan (Tabel 3).

Skala likert digunakan untuk mengidentifikasi jawaban dengan pemberian alternatif jawaban bagi pernyataan dengan skor minimal 1 hingga maksimal 5. Rancangan analisis data yang digunakan yaitu :

\section{Importance-Performance Analysis}

Tabel 3. Atribut bauran pemasaran (7P)

\begin{tabular}{|c|c|}
\hline Dimensi & Variabel \\
\hline Produk & $\begin{array}{ll}\text { - } & \text { Umur panen sesuai ketentuan (P1.1) } \\
\text { - } & \text { Ketahanan terhadap hama (P1.2) } \\
\text { - } & \text { Ketahanan terhadap penyakit (P1.3) } \\
\text { - } & \text { Keseragaman varietas (P1.4) } \\
\text { - } & \text { Kesesuaian dengan potensi hasil (P1.5) } \\
\text { - } & \text { Kualitas kemasan (P1.6) }\end{array}$ \\
\hline Harga & $\begin{array}{l}\text { - } \text { Kesesuaian harga dengan kualitas (P2.1) } \\
\text { - } \quad \text { Adanya potongan harga (P2.2) }\end{array}$ \\
\hline Saluran Distribusi & $\begin{array}{ll}\text { - } & \text { Lokasi kios strategis (P3.1) } \\
\text { - } & \text { Kelengkapan varietas benih (P3.2) }\end{array}$ \\
\hline Promosi & - $\quad$ Promosi word of mouth (P4.1) \\
\hline People & $\begin{array}{l}\text { - } \quad \text { Kemampuan melayani petani (P5.1) } \\
\text { - } \quad \text { Keramahan dan kesopanan pelayan (P5.2) }\end{array}$ \\
\hline Proses & $\begin{array}{ll}\text { - } & \text { Kecepatan pelayanan (P6.1) } \\
\text { - } & \text { Kecepatan penanganan keluhan (P6.2) }\end{array}$ \\
\hline Bukti Fisik & $\begin{array}{ll}\text { - } & \text { Tata letak produk (P7.1) } \\
\text { - } & \text { Kebersihan kios (P7.2) } \\
\end{array}$ \\
\hline
\end{tabular}

Menurut Swastika (2013), analisis ini digunakan untuk mengetahui tingkat kesesuaian antara penilaian petani terhadap kepentingan dan pelaksanaan bauran pemasaran.

a. Menghitung rata-rata kepentingan $\left(\mathrm{Y}_{\mathrm{i}}\right)$ dan pelaksanaan $\left(\mathrm{X}_{\mathrm{i}}\right)$

$\overline{\mathrm{Y}}=\frac{\sum \mathrm{Y}_{\mathrm{i}}}{\mathrm{n}} \operatorname{dan} \overline{\mathrm{X}}=\frac{\sum \mathrm{X}_{\mathrm{i}}}{\mathrm{n}}$

$\overline{\mathrm{Y}}=$ skor rata-rata kepentingan

$\overline{\mathrm{X}}=$ skor rata-rata pelaksanaan

$\mathrm{n}=$ jumlah responden

b. Menghitung Tingkat Kesesuaian

$$
\mathrm{Tk}_{\mathrm{i}}=\frac{\mathrm{X}_{\mathrm{i}}}{\mathrm{Y}_{\mathrm{i}}} \times 100 \%
$$

Keterangan :

$\mathrm{Tk}_{\mathrm{i}}=$ tingkat kesesuaian

$\mathrm{X}_{\mathrm{i}}=$ skor penilaian pelaksanaan

$\mathrm{Y}_{\mathrm{i}}=$ skor penilaian kepentingan
Keterangan: 
c. Membuat Diagram Kartesius

Diagram kartesius dibuat dengan SPSS 16.0 for Windows. Diagram Kartesius IPA disajikan pada Gambar 2.

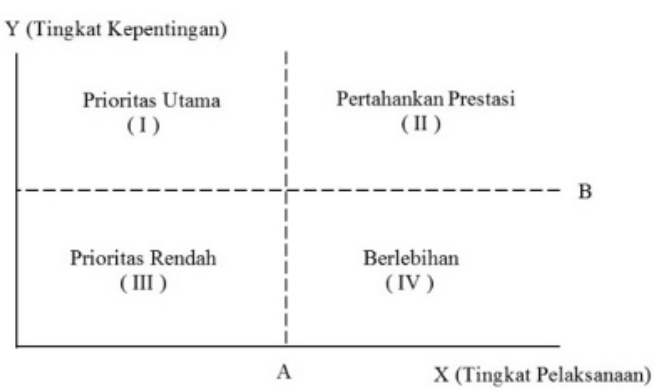

Gambar 2. Diagram Kartesius IPA

2. Customer Satisfaction Index (CSI)

a. Menentukan Mean Importance Score (MIS) dan Mean Satisfaction Score (MSS)

MIS $=\frac{\sum_{\mathrm{i}=1}^{\mathrm{n}} \mathrm{Y}_{\mathrm{i}}}{\mathrm{n}}$ dan MSS $=\frac{\sum_{\mathrm{i}=1}^{\mathrm{n}} \mathrm{X}_{\mathrm{i}}}{\mathrm{n}}$

Keterangan:

$\mathrm{Y}_{\mathrm{i}}=$ Tingkat kepentingan atribut bauran pemasaran ke-i

$\mathrm{X}_{\mathrm{i}}=$ Tingkat pelaksanaanatribut bauran pemasaran ke-i

$\mathrm{n}=$ jumlah responden

b. Membuat Weighted Factors (WF)

$\mathrm{WF}_{\mathrm{i}}=\frac{\mathrm{MIS}_{\mathrm{i}}}{\sum_{\mathrm{i}=1}^{\mathrm{p}} \mathrm{MIS}_{\mathrm{i}}} \times 100 \%$

Keterangan:

$\mathrm{p}=$ jumlah variabel kepentingan

$\mathrm{i}=$ variabel bauran pemasaran ke-i

c. Membuat Weighted Score (WS)

$\mathrm{WS}_{\mathrm{i}}=\mathrm{WF}_{\mathrm{i}} \times \mathrm{MSS}_{\mathrm{i}}$

Keterangan :

$\mathrm{i}=$ variabel bauran pemasaran $\mathrm{ke}-\mathrm{i}$

d. Menentukan Customer Satisfaction Index (CSI)

$\mathrm{CSI}=\frac{\sum_{\mathrm{i}=1}^{\mathrm{p}} \mathrm{WS}_{\mathrm{i}}}{5} \times 100 \%$

\section{HASIL DAN PEMBAHASAN}

\section{Analisis Tingkat Kesesuaian antara Kepentingan dan Pelaksanaan}

Perhitungan yang digunakan dalam analisis ini menggunakan rumus-rumus IPA yang telah dituliskan di atas. Berdasarkan Tabel 4. tingkat kesesuaian antara tingkat kepentingan dan tingkat pelaksanaan bauran pemasaran jumlahnya cukup tinggi, yaitu $83,23 \%$. Skor total tingkat kepentingan atribut ialah 2750, sedangkan tingkat pelaksanaannya adalah 2292. Hal ini berarti pelaksanaan bauran pemasaran masih berada di bawah kepentingan yang diharapkan petani. Namun perlu diteliti lebih lanjut mengenai atribut yang harus terlebih dahulu diperbaiki (dijadikan prioritas) dibandingkan atribut lainnya.

\section{Analisis Tingkat Kepentingan (Y) dan Tingkat Pelaksanaan (X)}

Penggunaan diagram kartesius dapat dilakukan untuk membagi skor-skor tersebut ke dalam empat buah kuadran (kuadran I - IV). Keempat kuadran tersebut akan menunjukkan atribut yang perlu diprioritaskan untuk diperbaiki, atribut yang perlu dipertahankan, atribut yang perlu diperbaiki namun tidak menjadi prioritas utama, dan atribut yang pelaksanaannya berlebihan. Pembagian skor dilakukan secara otomatis ke dalam empat kuadran yang dibatasi oleh dua buah garis berpotongan tegak lurus pada titik (A, B). A ialah skor rata-rata tingkat 
Tabel 4. Tingkat kesesuaian antara tingkat kepentingan dan tingkat pelaksanaan bauran pemasaran

\begin{tabular}{cccccc}
\hline Bauran Pemasaran & $\mathrm{Y}$ & $\overline{\mathrm{Y}}$ & $\mathrm{X}$ & $\overline{\mathrm{X}}$ & $\mathrm{Tk}_{\mathrm{i}}(\%)$ \\
\hline P1.1 & 169 & 4,69 & 141 & 3,92 & 83,58 \\
P1.2 & 170 & 4,72 & 128 & 3,56 & 75,42 \\
P1.3 & 172 & 4,78 & 126 & 3,50 & 73,22 \\
P1.4 & 145 & 4,03 & 139 & 3,86 & 95,78 \\
P1.5 & 146 & 4,06 & 123 & 3,42 & 84,24 \\
P1.6 & 166 & 4,61 & 146 & 4,06 & 88,07 \\
\hline P2.1 & 167 & 4,63 & 125 & 3,47 & 74,95 \\
P2.2 & 146 & 4,06 & 58 & 1,61 & 39,66 \\
\hline P3.1 & 164 & 4,56 & 150 & 4,17 & 91,45 \\
P3.2 & 168 & 4,67 & 149 & 4,14 & 88,65 \\
\hline P4.1 & 163 & 4,53 & 133 & 3,69 & 81,46 \\
\hline P5.1 & 162 & 4,5 & 142 & 3,94 & 87,56 \\
P5.2 & 158 & 4,39 & 157 & 4,36 & 99,32 \\
\hline P6.1 & 162 & 4,5 & 154 & 4,28 & 95,11 \\
P6.2 & 163 & 4,53 & 138 & 3,83 & 84,55 \\
\hline P7.1 & 165 & 4,58 & 149 & 4,14 & 90,39 \\
P7.2 & 164 & 4,56 & 134 & 3,72 & 81,58 \\
Rata-rata & & 4,49 & & 3,75 & 83,23
\end{tabular}

Keterangan: $\mathrm{Y}=$ kepentingan, $\overline{\mathrm{Y}}=$ rata-rata $\mathrm{Y}, \mathrm{X}=$ pelaksanaan, $\overline{\mathrm{X}}=$ rata-rata $\mathrm{X}$, dan $\mathrm{Tk}_{\mathrm{i}}=$ tingkat kesesuaian

pelaksanaan yaitu 3,75, sedangkan B ialah skor rata-rata tingkat kepentingan yaitu 4,49 (Tabel 4).

Setelah dilakukan penilaian terhadap tingkat kepentingan dan tingkat pelaksanaan bauran pemasaran serta kesesuaian antara keduanya, tahap selanjutnya yaitu meletakkan seluruh atribut bauran pemasaran yang dinilai responden pada kuadran masing-masing ke dalam Diagram Kartesius. Pembuatan diagram kartesius dilakukan menggunakan software SPSS 16.0 for Windows dan didapatkan hasil seperti yang disajikan pada Gambar 2.

\section{a. Kuadran I (Prioritas Utama)}

Atribut bauran pemasaran yang terdapat dalam kuadran I merupakan atribut yang dirasakan penting oleh petani padi, Tetapi kinerja yang dirasakan oleh pihak produsen dan pemasar belum mampu memenuhi harapan petani sehingga belum ada kepuasan yang dirasakannya. Atribut yang termasuk ke dalam kuadran I ini yaitu nomor 2, 3, 7, 11, dan 17 .

Petani berpendapat bahwa sangat penting bagi benih padi untuk tahan terhadap hama dan penyakit, karena 2-3 musim tanam produksi padi petani menurun bahkan gagal panen akibat serangan hama dan penyakit. 


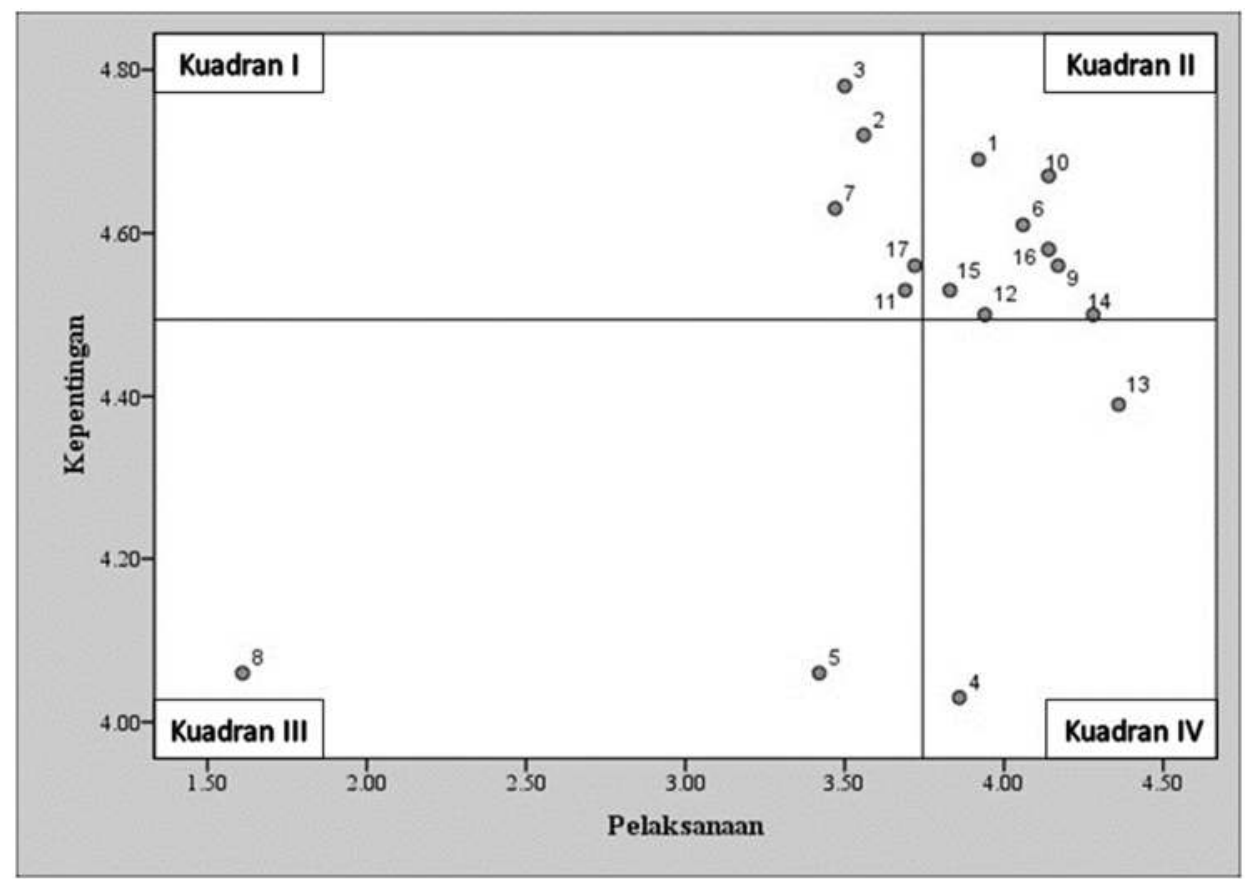

Gambar 3. Diagram Kartesius tingkat kepentingan (Y) dan tingkat kinerja (X) dari bauran pemasaran benih padi PT. Pertani. Keterangan: 1. kesesuaian umur panen padi dengan ketentuan; 2. ketahanan padi terhadap hama; 3. ketahanan padi terhadap penyakit, 4. keseragaman varietas benih, 5. kesesuaian jumlah produksi padi dengan potensi hasilnya, 6. kualitas kemasan benih PT. Pertani, 7. kesesuaian harga dengan kualitasnya, 8. adanya harga yang diberikan, 9. lokasi kios mitra PT. Pertani yang strategis, 10. kelengkapan varietas benih padi, 11. promosi word of mouth yang dilakukan, 12. kemampuan pelayan Kios Tani Ramah dalam melayani petani, 13. keramahan pelayan Kios Tani Ramah, 14. kecepatan pelayanan Kios Tani Ramah, 15. kecepatan penanganan keluhan oleh kio, 16. tata letak produk di Kios Tani Ramah, dan 17. kebersihan Kios Tani Ramah.

Mengenai kesesuaian harga benih dengan kualitas (7), banyak petani yang merasa keberatan dengan harga yang ditawarkan oleh PT. Pertani. Alasannya, modal yang direncanakan tidak hanya untuk membeli benih, banyak kebutuhan lain yang harus dipenuhi seperti biaya mengolah tanah, pemupukan, dan lainnya.

Promosi word of mouth (11) atau promosi dari mulut ke mulut dinilai sangat penting oleh petani. Selama ini masih banyak petani yang tidak terlalu paham akan benih PT. Pertani secara mendalam, mereka cenderung hanya mengetahui varietas yang digunakan tanpa mengenali mereknya. Melalui promosi dari mulut ke mulut secara mendalam, proses pengenalan (terutama pengenalan merek) produk kepada konsumen dapat terlaksana bahkan saat pemasar tidak terlibat langsung.

Terkait kebersihan Kios Tani Ramah (17) yang menjadi salah satu indikator dari bauran pemasaran physical evidence, responden merasa kinerja ini perlu ditingkatkan. Terbukti dengan adanya responden yang memilih jawaban tidak baik pada penilaian kinerjanya. Responden berpendapat kebersihan penting supaya 
petani merasa nyaman dan konsentrasi saat berbelanja di kios. Alasan lain yaitu supaya produk yang dijual kios terjamin kualitasnya. Beberapa responden berpendapat kios lain yang pernah dikunjunginya lebih bersih dari Kios Tani Ramah.

\section{b. Kuadran II (Pertahankan Prestasi)}

Kuadran II memiliki makna bahwa tingkat kepentingan menurut petani dan tingkat pelaksanaan sama-sama penting dan baik. Maka posisi atribut-atribut bauran pemasaran yang ada pada kuadran II harus dipertahankan baik oleh pihak PT. Pertani cabang Pemasaran Karawang maupun Kios Tani Ramah. Tujuannya supaya kepuasan petani selalu terpenuhi. Dalam penelitian ini, atribut bauran pemasaran paling banyak berada di kuadran II, itu berarti banyak pelaksanaan atribut yang memuaskan petani dalam bertransaksi benih padi ini. Adapun atribut yang termasuk dalam kuadran II yaitu nomor 1, 6, 9, 10, 12, 14, 15, dan 16 .

Pertama dari segi umur panen (1), tanaman padi yang berasal dari benih sudah sesuai ketentuan umum yaitu sekitar 95 100 hari. Kedua dari segi kemasan (6), kemasan benih dianggap sudah baik karena terbuat dari bahan plastik yang mampu mempertahankan kadar air (Kobarsih, 2011), walaupun ada petani yang menyarankan agar tulisan merek diperbesar supaya memudahkan petani untuk mengenalinya. Ketiga mengenai kestrategisan lokasi dari kios (9), letak Kios Tani Ramah memang berada disisi jalan raya. Keempat, dari segi kelengkapan varietas (10) sebagian besar petani sudah puas dengan kinerja ini. Kelima, dari segi kemampuan pelayan kios (12), responden menganggap cara pemilik kios mengorganisir barangnya sudah baik. Lalu untuk kecepatan pelayanannya (14) pun secara umum sudah baik, pelayan di kios mampu melayani dengan cepat sekalipun kios sedang ramai dan sibuk. Kecepatan penanganan keluhan dari kios (15)pun dapat dikatakan baik, terbukti sebagian besar responden menyatakan bahwa penangananan keluhan oleh kios cepat. Dan terakhir, mengenai tata letak produk di Kios Tani Ramah (16), para petani merasa oleh karena ukuran kios yang cukup luas dibandingkan pesaingnya, produk-produk yang ada di kios terlihat lebih tertata sesuai kategorinya.

\section{c. Kuadran III (Prioritas Rendah)}

Kuadran III ini memuat atribut yang dirasa kurang penting oleh petani, dan kinerjanya juga dirasa kurang baik. Maka dari itu kuadran ini disebut dengan istilah prioritas rendah. Perbaikan diperlukan untuk kinerjanya namun ada yang harus lebih didahulukan, yakni atribut pada kuadran I. Adapun atribut yang berada di kuadran III yaitu atribut 5 dan 8 .

Atribut kesesuaian jumlah produksi padi dengan potensi hasilnya (5) dirasakan 
cukup penting bagi petani, sebab mereka menjadikan potensi hasil ini sebagai acuan untuk hasil yang akan didapat nantinya. Sedangkan untuk potongan harga (8), atribut ini mendapat penilaian kinerja yang rendah karena SOP untuk potongan harga dari PT. Pertani sendiri baru ada pada bulan Februari 2018 sehingga konsumen (petani) belum merasakannya.

\section{d. Kuadran IV (Berlebihan)}

Atribut pada kuadran ini yaitu atribut yang dirasakan kurang penting namun PT. Pertani dan Kios Tani Ramah telah melaksanakannya dengan baik. Atributatribut tersebut ialah nomor 4 dan 13. Tetapi bukan berarti kedua atribut tersebut perlu diturunkan kinerjanya

Pada atribut keseragaman varietas benih (4), beberapa petani menganggap hal ini tidak begitu penting karena walaupun ada sedikit varietas lain di hasil panennya, hasil tersebut tetap laku terjual. Sedangkan pada atribut keramahan pelayan kios (13), penilaian kepentingan berada dibawah ratarata atribut lainnya, sedangkan penilaian pelaksanaan berada di atas rata-rata. Hal tersebut yang menyebabkan atribut ini masuk ke dalam kuadran IV.

\section{Analisis Indeks Kepuasan Konsumen (CSI)}

Sesuai dengan namanya, perhitungan Customer Satisfaction Index (CSI) atau indeks kepuasan konsumen digunakan untuk menentukan tingkat kepuasan konsumen secara keseluruhan melalui pendekatan yang mempertimbangan tingkat kepentingan dari atribut yang diukurnya. Indeks kepuasan konsumen didapatkan melalui nilai rata-rata tingkat kepentingan dan nilai rata-rata tingkat pelaksanaan (Swastika, 2013). Penelitian ini bertujuan untuk mengetahui berapa indeks kepuasan konsumen terhadap bauran pemasaran benih padi non subsidi produksi PT. Pertani. Setelah dilakukan perhitungan tingkat kepentingan dan tingkat pelaksanaan menggunakan Importance Performance Analysis (IPA), langkah berikutnya ialah menentukan indeks kepuasan konsumen yang dapat dilihat pada Tabel 5.

Berdasarkan penelitian yang dilakukan terhadap petani (konsumen) yang membeli benih padi bersertifikat non subsidi PT. Pertani di Kios Tani Ramah, diperoleh indeks kepuasan petani sebesar $75,20 \%$ atau 0,752 . Hasil dari perhitungan CSI ini berada pada rentang $0,66-0,80$, yang berarti bahwa petani sebagai konsumen benih padi PT. Pertani telah merasa puas terhadap pelaksanaan bauran pemasaran yang diteliti. Oleh karena itu, baik PT. Pertani maupun Kios Tani Ramah harus dapat mempertahankan pelaksanaan bauran pemasarannya, sehingga petani akan tetap merasa puas dan setia menggunakan benih padi bersertifikat non subsidi PT. Pertani, serta membelinya di Kios Tani Ramah. 
Tabel 5. Perhitungan Customer Satisfaction Index (CSI)

\begin{tabular}{|c|c|c|c|c|c|c|c|}
\hline No & Atribut Bauran Pemasaran & Y & MIS & WF (\%) & $\mathrm{X}$ & MSS & WS \\
\hline 1 & Umur panen padi sesuai ketentuan & 169 & 4,69 & 6,14 & 141 & 3,92 & 0,24 \\
\hline 2 & Ketahanan terhadap hama & 170 & 4,72 & 6,18 & 128 & 3,56 & 0,22 \\
\hline 3 & Ketahanan terhadap penyakit & 172 & 4,78 & 6,26 & 126 & 3,5 & 0,22 \\
\hline 4 & Keseragaman varietas & 145 & 4,03 & 5,27 & 139 & 3,86 & 0,2 \\
\hline 5 & Kesesuaian dengan potensi hasil & 146 & 4,06 & 5,31 & 123 & 3,42 & 0,18 \\
\hline 6 & Kualitas kemasan & 166 & 4,61 & 6,03 & 146 & 4,06 & 0,25 \\
\hline 7 & Kesesuaian harga dengan kualitas & 167 & 4,63 & 6,06 & 125 & 3,47 & 0,21 \\
\hline 8 & Adanya potongan harga & 146 & 4,06 & 5,31 & 58 & 1,61 & 0,09 \\
\hline 9 & Lokasi kios strategis & 164 & 4,56 & 5,97 & 150 & 4,17 & 0,25 \\
\hline 10 & Kelengkapan varietas benih & 168 & 4,67 & 6,12 & 149 & 4,14 & 0,25 \\
\hline 11 & Promosi word of mouth & 163 & 4,53 & 5,93 & 133 & 3,69 & 0,22 \\
\hline 12 & Kemampuan melayani petani & 162 & 4,5 & 5,89 & 142 & 3,94 & 0,23 \\
\hline 13 & $\begin{array}{l}\text { Keramahan dan kesopanan } \\
\text { pelayan }\end{array}$ & 158 & 4,39 & 5,75 & 157 & 4,36 & 0,25 \\
\hline 14 & Kecepatan pelayanan & 162 & 4,5 & 5,89 & 154 & 4,28 & 0,25 \\
\hline 15 & Kecepatan penanganan keluhan & 163 & 4,53 & 5,93 & 138 & 3,83 & 0,23 \\
\hline 16 & Tata letak produk & 165 & 4,58 & 5,99 & 149 & 4,14 & 0,25 \\
\hline \multirow[t]{4}{*}{17} & Kebersihan kios & 164 & 4,56 & 5,97 & 134 & 3,72 & 0,22 \\
\hline & & $\Sigma$ MIS & 76,4 & 100 & $\Sigma \mathrm{MSS}$ & 63,67 & 3,76 \\
\hline & Rata-rata & & 4,49 & & & 3,75 & \\
\hline & \multicolumn{7}{|c|}{$\mathrm{CSI}=(3,76) / 5=0,752 \times 100 \%=75,20 \%$} \\
\hline
\end{tabular}

Keterangan: $\mathrm{Y}=$ tingkat kepentingan, $\mathrm{MIS}=$ mean importance score, $\mathrm{WF}=$ weighted factors $(\%), \mathrm{X}=$ tingkat kinerja, MSS = mean satisfaction score, $\mathrm{WS}=$ weighted score, dan CSI = customer satisfaction index.

\section{KESIMPULAN}

1. Berdasarkan hasil penelitian, diketahui bahwa kepuasan petani terhadap bauran pemasaran benih padi bersertifikat non subsidi PT. Pertani berdasarkan penilaian dengan metode CSI adalah $75,20 \%$, yang artinya petani merasa puas dengan seluruh kinerja atau pelaksanaan bauran pemasaran.

2. Saran perbaikan untuk atribut bauran pemasaran berdasarkan hasil kuadran IPA yaitu bahwa atribut ketahanan hama, ketahanan penyakit, kesesuaian harga dengan kualitas benih, promosi word of mouth oleh pihak PT. Pertani, dan kebersihan kios menjadi prioritas utama untuk diperbaiki kinerjanya.

\section{DAFTAR PUSTAKA}

BPS. 2016. Produksi padi menurut provinsi (ton) 2006-2015. (on-line), Badan Pusat Statistik. https://www.bps.go.id/ linkTableDinamis/view/id/865. Diakses 26 Desember 2017.

Direktorat Perbenihan Tanaman Pangan. 2015. Laporan kinerja instansi pemerintah tahun 2015. Direktorat Jenderal Tanaman Pangan, Departemen Pertanian, Jakarta. 37p.

Mevita, A. S. 2015. Pengaruh bauran pemasaran terhadap kepuasan 
konsumen. Jurnal Ilmu \& Riset Manajemen, 2(9): 1 - 18.

Rachman, B., I.W. Rusastra, dan K. Kariyasa. 2004. Sistem pemasaran benih dan pupuk dan pembiayaan usahatani. (on-line). Pusat Penelitian dan Pengembangan Sosial Ekonomi Pertanian. http://pse.litbang. pertanian.go.id/ind/pdffiles/pros08_2004.pdf. Diakses 22 Desember 2017.

Rahayu, S., Y.P. Wanita dan M. Kobarsih. 2011. Penyimpanan benih padi menggunakan berbagai jenis pengemas. Agrin, 15(1): 36 - 44 .

Sodikin, D. M. 2015. Kajian persepsi petani dan produksi penggunaan benih bersertifikat dan non sertifikat pada usahatani padi. Skripsi. Agribisnis, Universitas Jember. 58p.

Sudjindro. 2009. Permasalahan dalam Implementasi Sistem Perbenihan. Buletin Tanaman Tembakau, Serat \& Minyak Industri, 1(2): $92-100$.

Swastika, N., T. Yanto, dan A. Hartati. 2013. Performansi kualitas atribut beras organik dan tingkat kepuasan konsumen beras organik di Kabupaten Sragen. Agrin, 17(2): 103 - 112.

Wulandari, E., M. P. M. Meuwissen, M. H. Karmana, and A. G. J. M. O. Lansink. 2017. Access to finance from different finance provider types: farmer knowledge of the requirements. Plos One, 12(9), e0179285. 